An anomal ous hydr at i on/dehydr at i on sequence for the mild gener at i on of a nitrile oxi de

\begin{tabular}{|l|l|}
\hline 著者 & $\begin{array}{l}\text { N shi waki Nagat oshi, Kobi ro Kazuya, Ki yot o } \\
\text { H deyuki, H rao Shot ar o, Sawayama J un, Sai go } \\
\text { Kazuhi ko, Okaj i ma Yoshi kazu, Uehar a Toshi har u, } \\
\text { Naki Asaka, Ar i ga Masahi ro }\end{array}$ \\
\hline $\begin{array}{l}\text { j our nal or } \\
\text { publ i cat i on ti tl e }\end{array}$ & Or gani c \& Bi ond ecul ar Chemi st ry \\
\hline vol une & 9 \\
\hline number & 8 \\
\hline page range & $2832-2839$ \\
\hline year & 2011 \\
\hline URL & ht t p: //hdl . handl e. net /10173/1346 \\
\hline
\end{tabular}




\title{
An anomalous hydration/dehydration sequence for the mild generation of a nitrile oxide
}

\author{
Nagatoshi Nishiwaki, $*^{a}$ Kazuya Kobiro, ${ }^{a}$ Hideyuki Kiyoto, ${ }^{a}$ Shotaro Hirao, ${ }^{a}$ Jun Sawayama, ${ }^{a}$ Kazuhiko \\ Saigo, ${ }^{a}$ Yoshikazu Okajima, ${ }^{b}$ Toshiharu Uehara, ${ }^{b}$ Asaka Maki ${ }^{b}$ and Masahiro Ariga ${ }^{b}$
}

\author{
${ }_{5}$ Received (in $\left.X X X, X X X\right)$ Xth $X X X X X X X X X 200 X$, Accepted Xth XXXXXXXXX 200X \\ First published on the web Xth $X X X X X X X X X 200 X$ \\ DOI: 10.1039/b000000x
}

A nitrile oxide having a carbamoyl group is readily generated upon the treatment of 2-methyl-4nitro-3-isoxazolin-5(2H)-one with water under mild reaction conditions, even in the absence of

10 special reagents. The obtained nitrile oxide undergoes cycloaddition with dipolarophiles, alkynes and alkenes, to afford the corresponding isoxazol(in)es, which are useful intermediates in the synthesis of polyfunctionalized compounds. A plausible mechanism underlying the formation of the nitrile oxide is proposed, which involves an anomalous hydration/dehydration sequence. DFT calculations were also performed to support this mechanism.

\section{${ }_{15}$ Introduction}

1,3-Dipolar cycloaddition plays an important role in synthetic chemistry because it affords five-membered heterocyclic rings in a single step. Moreover, the cycloadducts formed in this reaction and the ring-opened products obtained from the 20 adducts are precursors of a variety of versatile functional materials. ${ }^{1}$ With the growing demand for environmentfriendly synthesis protocols, there has been increased focus on 1,3-dipolar cycloaddition reactions in aqueous media. ${ }^{2}$ Nitrile oxide, one of the most popular classes of 1,3-dipoles, affords 25 isoxazoles, 2-isoxazolines, and 1,2,4-oxadiazoles upon treatment with alkynes, alkenes, and nitriles, respectively. ${ }^{1-4}$ While there are numerous reports on nitrile oxides, most of them are related to aryl- or alkyl-substituted nitrile oxides. Nitrile oxides having a suitable functional group are 30 considered useful for the synthesis of functional materials; however, such substituted nitrile oxides are not very common in organic synthesis, probably because they are highly reactive and their precursors are not readily availabile.
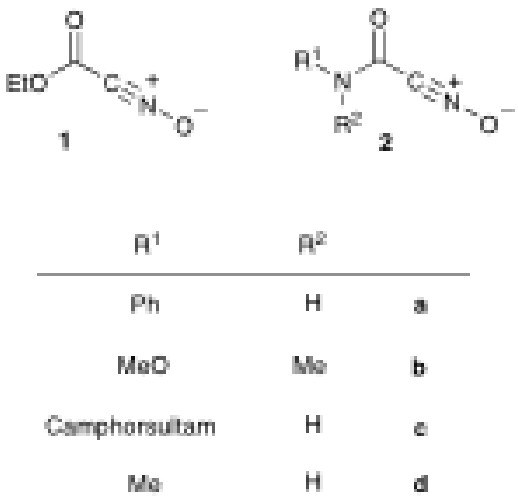

35

Figure 1. Nitrile oxides having a functional group.
Among the various functionalized nitrile oxides reported, the 40 ethoxycarbonyl derivative $\mathbf{1}$ is most commonly used in organic synthesis. Nitrile oxide $\mathbf{1}$ is generated by the dehydrochlorination of hydroximoyl chlorides, which is synthesized from ethyl glyoxylate or glycine ethyl ester. ${ }^{5}$ A method for the dehydration of ethyl nitroacetate to $\mathbf{1}$ has also 45 been established; in this reaction, tolylene diisocyanate (modified Mukaiyama method), ${ }^{6}$ manganese(III) acetate, ${ }^{7}$ acid chloride, $^{8}$ or trifluoroborane etherate ${ }^{9}$ is employed as the generating agent. In addition, nitromalonate ${ }^{10}$ and nitroacetoacetate ${ }^{11}$ are known to be precursors of $\mathbf{1}$; however, 50 these compounds have certain disadvantages: severe reaction conditions must be employed when using nitromalonate, and nitroacetoacetate is highly unstable. Although De Sarlo and Machetti demonstrated an excellent protocol for preparation of functionalized isoxazol(in)es from nitroalkanes, active 55 species were not functionalized nitrile oxides but activated nitronates. $^{12}$

Nitrile oxides bearing an amide function have not been widely utilized in organic syntheses, except in a few intriguing cases. Paul and Tchelitcheff were the first to isolate 60 the cycloadduct of $N$-phenylcarbamoylnitrile oxide 2a as a byproduct in a reaction between nitromethane, phenyl isocyanate, and triethylamine. ${ }^{13}$ Huisgen and Christl showed that $\mathrm{N}$ phenylnitroacetamide is the precursor of $2 \mathbf{a}$ in the above mentioned reaction. ${ }^{14}$ Joule et al. also generated a 65 carbamoylnitrile oxide by treating nitroacetamide with thionyl chloride. $^{8 \mathrm{a}}$ Shimizu, ${ }^{15}$ Webb, $^{6 \mathrm{~b}}$ and Schults $^{16}$ reported a different method involving the use of $\alpha$-nitromalonic acid amide ester $\mathbf{3 a}$ as a precursor for generating $\mathbf{2} \mathbf{a}$; however, in this method, severe reaction conditions were required 70 (Scheme 1). Moreover, although dehydrochlorination of carbamoylformhydroxymoyl chloride by triethylamine is also known to be another route to $\mathbf{2 a}$, multi-step reactions are necessary for preparation of the starting chloride. ${ }^{17}$ Recently, nitrile oxides having an $N$-modified carbamoyl group such as ${ }_{75}$ Weinreb amide $2 \mathbf{b}^{18}$ and chiral amide $\mathbf{2} \mathbf{c}^{19}$ have been synthesized. Although these nitrile oxides possess inherent 
high synthetic values, the corresponding precursors are troublesome to prepare. Therefore, development of a facile method to generate $\mathbf{2}$ under mild conditions is necessary. In the present paper, we demonstrate a new route to 5 carbamoylnitrile oxide 2d from 2-methyl-4-nitro-3-isoxazolin$5(2 \mathrm{H})$-one (5a) which can be easily prepared as shown in Scheme $2 .^{20}$
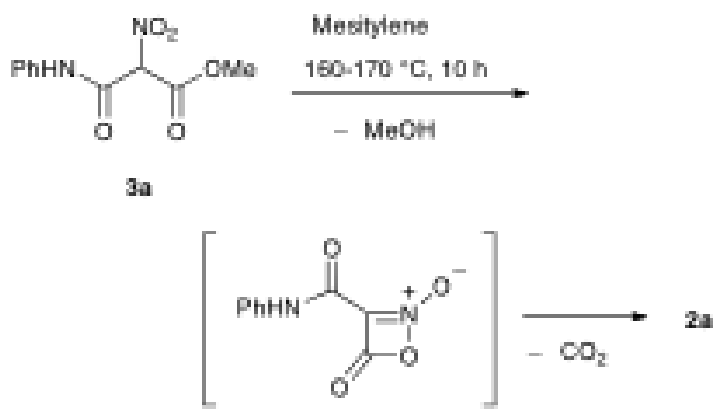

Scheme 1. Conversion of malonic acid amide ester 3a to nitrile oxide 2a.
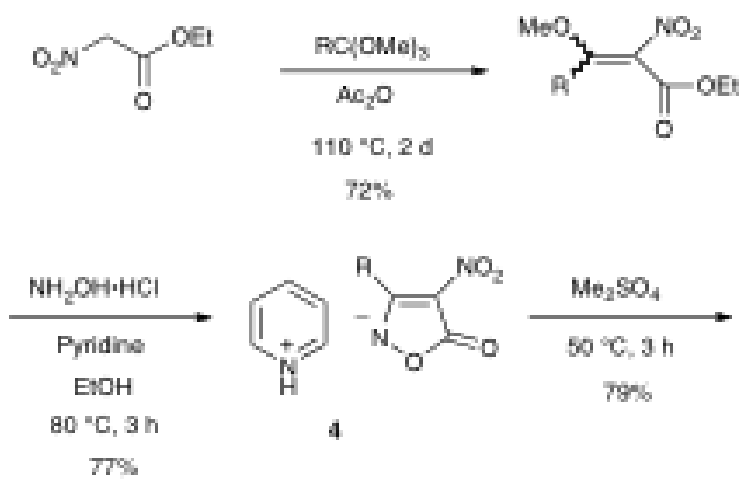

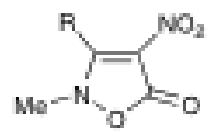

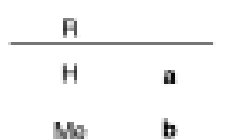

Mo b
Scheme 2. Preparation of nitroisoxazolone 5.

\section{Results and Discussion}

Nitroisoxazolone 5a readily reacted with amines to afford $\alpha$ amino- $\beta$-nitroenamines (nitroketene aminals) and 20 amidoximes $^{21}$ and underwent ring transformation to afford polyfunctionalized pyrroles upon treatment with sodium enolates of 1,3-dicarbonyl compounds (Scheme 3). ${ }^{22}$ Upon heating in DMF at $100{ }^{\circ} \mathrm{C}$ in the absence of nucleophile, isoxazolone $\mathbf{5 a}$ was found to remain intact, but bubbles were 25 formed in the reaction mixture after activated carbon was added. From this mixture, bis( $N$-methylcarbamoyl)-1,2,5oxadiazole-2-oxide (furoxan) (6) could be isolated in $40 \%$ yield (based on 5a), indicating the in situ generation of carbamoylnitrile oxide (2d, $\left.\mathrm{R}^{1}=\mathrm{Me}, \mathrm{R}^{2}=\mathrm{H}\right)$ from 30 nitroisoxazolone $\mathbf{5 a}$ and the concurrent elimination of carbon dioxide. However, the role of activated carbon in this reaction has not yet been clarified. Cycloaddition of $\mathbf{2 d}$ proceeded to afford 3-( $N$-methylcarbamoyl)-5-phenylisoxazole (8a) in 66\% yield when activated carbon was added to a solution of $\mathbf{5 a}$ and 35 ethynylbenzene $7 \mathbf{a}$ under the same conditions mentioned above (heating at $100{ }^{\circ} \mathrm{C}$ in DMF). ${ }^{23} \mathrm{~A}$ small amount of furoxan 6 was also isolated from the aqueous solution used for the workup of the other reaction involving nitroisoxazolone 5a. In this case, nitrile oxide $\mathbf{2 d}$ was formed even when 40 activated carbon was not employed, indicating that this nitrile oxide was generated by another generating agent, presumably water. This hypothesis prompted us to reinvestigate the generation of carbamoylnitrile oxide $\mathbf{2 d}$ in aqueous media.

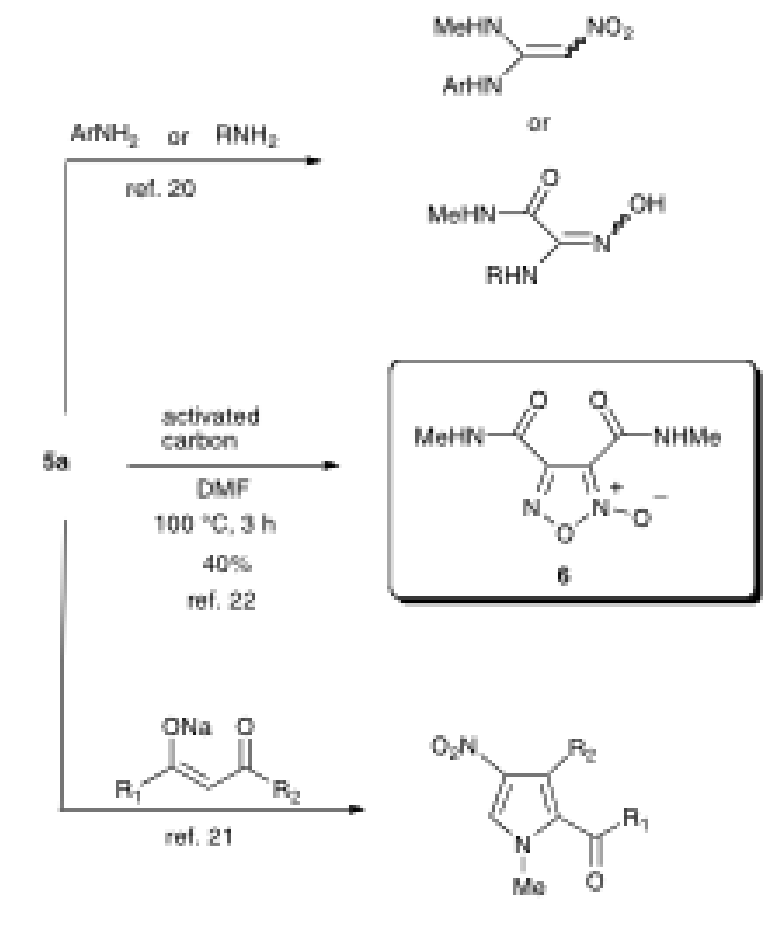

Scheme 3. Chemical transformation of nitroisoxazolone 5a.

An aqueous solution of nitroisoxazolone 5a was stirred at $30{ }^{\circ} \mathrm{C}$ for 1 day without adding any other reagent, and then, 50 water was removed under reduced pressure. The residue was purified by silica gel column chromatography to afford furoxan $\mathbf{6}$ in $80 \%$ yield (based on 5a), together with a trace amount of $\mathrm{N}$-methylnitroacetamide $\mathbf{9 .}^{24}$ The successful isolation of furoxan $\mathbf{6}$ indicated that water triggered the 55 generation of nitrile oxide $\mathbf{2 d}$ under the abovementioned reaction conditions, as expected. Cycloaddition of $\mathbf{2 d}$ to $\mathbf{7 a}$ proceeded under the same conditions mentioned above to afford isoxazole $\mathbf{8 a}$ in $22 \%$ yield (Table 1 , run 1 ). Since the low efficiency of the cycloaddition reaction was attributed to 60 the low solubility of $\mathbf{7 a}$ in water, an acetonitrile/water (3/1, 
$v / v$ ) mixture was used to improve the solubility of both isoxazolone 5a and the dipolarophile 7a. Although the amount of water could be diminished to the ratio $(6 / 1, v / v)$, almost all nitroisoxazolone 5 a was recovered in the case of $(9 / 1, v / v)$ 5 ratio (runs 2-4). Under these conditions, considerable amounts of furoxan 6 were formed as the by-product; a similar result was obtained even at higher temperature (run 5). The above disadvantage was overcome by using excess dipolarophile, and the yield of $\mathbf{8 a}$ in this case was improved up to $72 \%$ (run 106 ). When THF was used as a co-solvent in the present reaction, the yield of $\mathbf{8 a}$ was comparable to that mentioned in the previous sentence (run 7); however, acetonitrile was preferred because of the high solubility of $\mathbf{5 a}$ in this solvent.

15 Table 1. Study on reaction conditions.

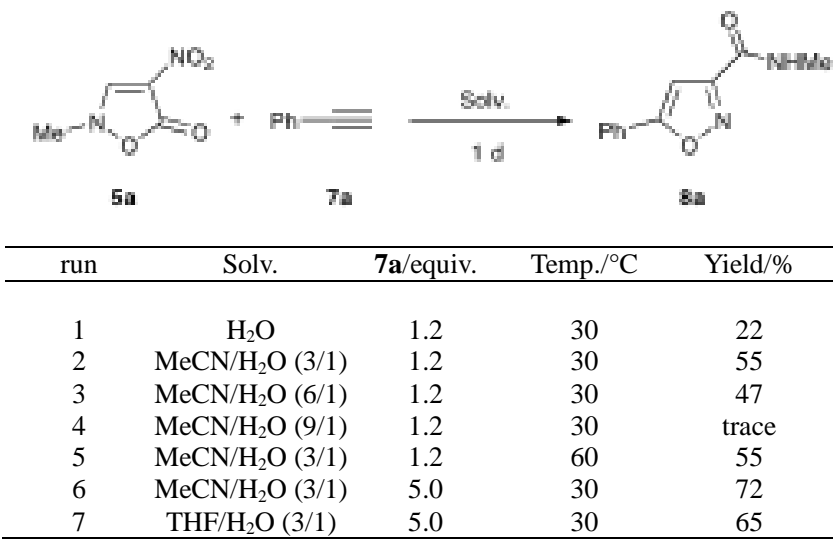

Other dipolarophiles $\mathbf{7 b}$-d and 10a-l were subjected to 20 cycloaddition under the optimized conditions used for ethynylbenzene $\mathbf{7 a}$ (Table 2, run 1). Propargyl derivatives $\mathbf{7 b}$ and 7c underwent this cycloaddition reaction to afford cycloadducts $\mathbf{8 b}$ and $\mathbf{8 c}$, respectively (runs 2 and 3). A trifunctionalized isoxazole $\mathbf{8 d}$ was prepared in a similar 25 manner from electron-deficient alkyne 7d (run 4). Nitrile oxide 2d also underwent the aforementioned cycloaddition with olefinic hydrocarbons 10a-c to afford the corresponding 2-isoxazolines (4,5-dihydroisoxazoles) 11a-c (runs 5-7). Allyl alcohol 10d had higher reactivity than did hydrocarbons and 30 allyl ethyl ether $\mathbf{1 0 e}$; the hydroxy group in $\mathbf{1 0 d}$ was thought to participate in the generation of nitrile oxide $\mathbf{2 d}$ (runs 8 and 9). On the other hand, allylamine $\mathbf{1 0 f}$ afforded a complex mixture, in which desired cycloadduct 11f could not be detected presumably because of competitive reactions triggered by the 35 nucleophilic amino group, as shown in Scheme 3 (run 10). This problem was partially solved by protecting the amino group with an acetyl group, in which case $\mathbf{1 1 g}$ was obtained, albeit in low yield (run 11). The present reaction was applicable to electron-rich alkenes such as vinyl ethers $\mathbf{1 0 h}$ 40 and $\mathbf{1 0} \mathbf{i}$ as well as to electron-deficient alkenes such as acrylate $\mathbf{1 0 j}$, maleate $\mathbf{1 0 k}$, and enone $\mathbf{1 0 l}$ : alkenes $\mathbf{1 0 h}-\mathbf{l}$ gave the corresponding cycloadducts $\mathbf{1 1 h}-\mathbf{l}$ in good to excellent yields (runs 12-16). It is noteworthy that the cycloaddition of 2d with monosubstituted alkenes proceeded regioselectively 45 to afford 5-substituted 2-isoxazolines $\mathbf{1 1}$ independent of the electronic property of the dipolarophiles.
Table 2. Cycloaddition of nitrile oxide $2 \mathbf{d}$ generated from $\mathbf{5 a}$ and dipolarophiles $\mathbf{7}$ and $\mathbf{1 0 .}$

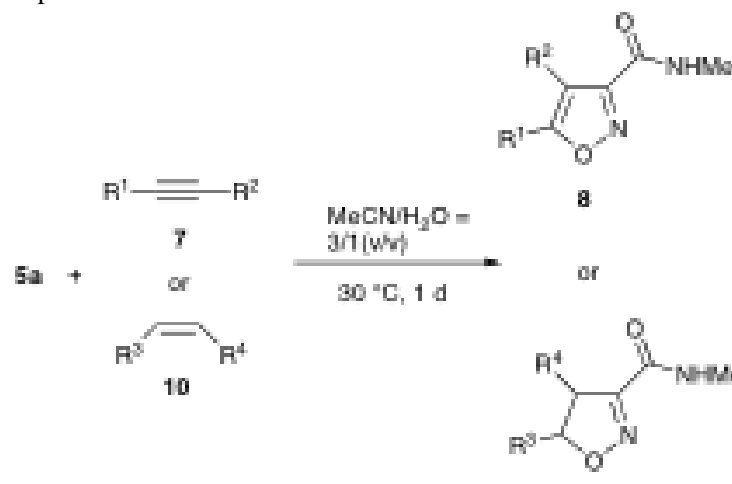

11

\begin{tabular}{|c|c|c|c|c|c|c|c|}
\hline run & Substrate & $\mathrm{R}^{1}$ & $\mathrm{R}^{2}$ & $\mathrm{R}^{3}$ & $\mathrm{R}^{4}$ & Product & Yield/\% \\
\hline 1 & $7 \mathbf{a}$ & $\mathrm{Ph}$ & $\mathrm{H}$ & & & $8 a$ & 72 \\
\hline 2 & $7 \mathbf{b}$ & $\mathrm{CH}_{2} \mathrm{OH}$ & $\mathrm{H}$ & & & $8 b$ & 84 \\
\hline 3 & 7c & $\mathrm{CH}_{2} \mathrm{Br}$ & $\mathrm{H}$ & & & $8 c$ & 58 \\
\hline 4 & $7 d$ & COOEt & COOEt & & & 8d & 74 \\
\hline 5 & $10 a$ & & & $\mathrm{Ph}$ & $\mathrm{H}$ & 11a & 85 \\
\hline 6 & $10 \mathrm{~b}$ & & & $\operatorname{Pr}$ & $\mathrm{H}$ & 11b & 73 \\
\hline 7 & 10c & & & $-\left(\mathrm{CH}_{2}\right)_{3^{-}}$ & & 11c & 63 \\
\hline 8 & 10d & & & $\mathrm{CH}_{2} \mathrm{OH}$ & $\mathrm{H}$ & 11d & quant. \\
\hline 9 & $10 \mathrm{e}$ & & & $\mathrm{CH}_{2} \mathrm{OEt}$ & $\mathrm{H}$ & 11e & 76 \\
\hline 10 & $10 f$ & & & $\mathrm{CH}_{2} \mathrm{NH}_{2}$ & $\mathrm{H}$ & 11f & 0 \\
\hline 11 & $10 \mathrm{~g}$ & & & $\mathrm{CH}_{2} \mathrm{NHAC}$ & $\mathrm{H}$ & 11g & 23 \\
\hline 12 & $10 \mathrm{~h}$ & & & OEt & $\mathrm{H}$ & 11h & 78 \\
\hline 13 & $10 \mathrm{i}$ & & & $-\left(\mathrm{CH}_{2}\right)_{2} \mathrm{O}-$ & & $11 \mathrm{i}$ & 78 \\
\hline 14 & $\mathbf{1 0 j}$ & & & COOEt & $\mathrm{H}$ & 11j & 92 \\
\hline 15 & $10 \mathbf{k}$ & & & COOMe & COOMe & $11 k$ & $67^{\mathrm{a}}$ \\
\hline 16 & 101 & & & COMe & $\mathrm{H}$ & 111 & 63 \\
\hline
\end{tabular}

${ }^{\text {a }}$ A mixture of cis- and trans-isomers was formed in a 93/7 ratio.

50

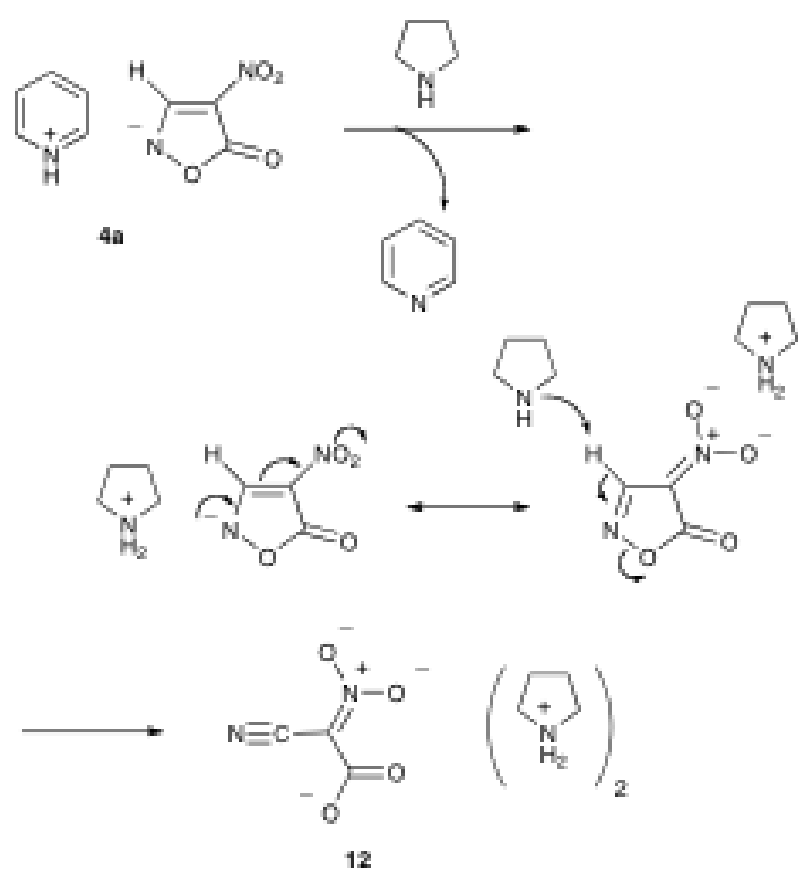

Scheme 4. Ring opening reaction of anionic isoxazolone 4a 
We have previously demonstrated that the anionic nitroisoxazolone 4a undergoes ring opening to form dianionic cyano-aci-nitroacetate 12 by cation exchange and subsequent deprotonation at the 3-position of the isoxazolone ring (Scheme $\left.{ }_{5} 4\right) .{ }^{20 c}$ Since even anionic isoxazolone $4 \mathbf{a}$ is deprotonated by pyrrolidine, the ring proton of $N$-methylisoxazolone $\mathbf{5 a}$ should be sufficiently acidic for easy deprotonation by water. 2,3Dimethylnitroisoxazolone $\mathbf{5 b},{ }^{25}$ which has no ring protons, remains intact under the same conditions to be recovered, 10 although the steric effect of the additional methyl group in this compound must be taken into consideration. On the basis of these observations, we propose a plausible mechanism for the generation of nitrile oxide $\mathbf{2 d}$, as shown in Scheme 5. According to this mechanism, the first step in the formation of $\mathbf{2 d}$ is
15 deprotonation at the 3-position by water. The successive ringopening reaction furnishes the ketenimine intermediate 13. As reviewed by Prager and Williams, ${ }^{26}$ a number of base-induced ring-opening reactions of 3-isoxazolin-5-ones have been studied; in these reactions, the $\mathrm{N}-\mathrm{O}$ bond fission initiated by deprotonation 20 at the 3-position affords malonic acid derivatives via the formation of ketenimine and $\beta$-lactone intermediates. ${ }^{27}$ In our reaction, the cummulene carbon of ketenimine $\mathbf{1 3}$ is attacked by water to afford $\alpha$-hydroxy- $\beta$-nitroenamine $\mathbf{1 4}$ (route a), which in turn undergoes a tautomeric rearrangement to form 25 nitroacetamide $\mathbf{9}$ by tautomerism. Another reaction path (route $\mathbf{b}$ ), which involves the intramolecular attack of carboxylate on the cummulene carbon to give $\beta$-lactone $\mathbf{1 5}$, can also be considered.

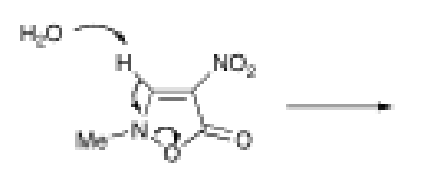

5a

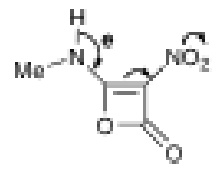

15<smiles>CCCCC(=O)C1OC(=NC)C(=N[N+](=O)O)C1O</smiles>

16

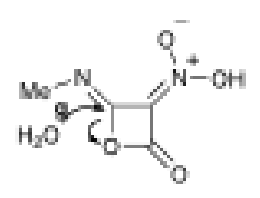

16

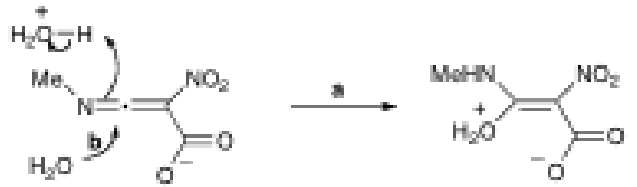

13

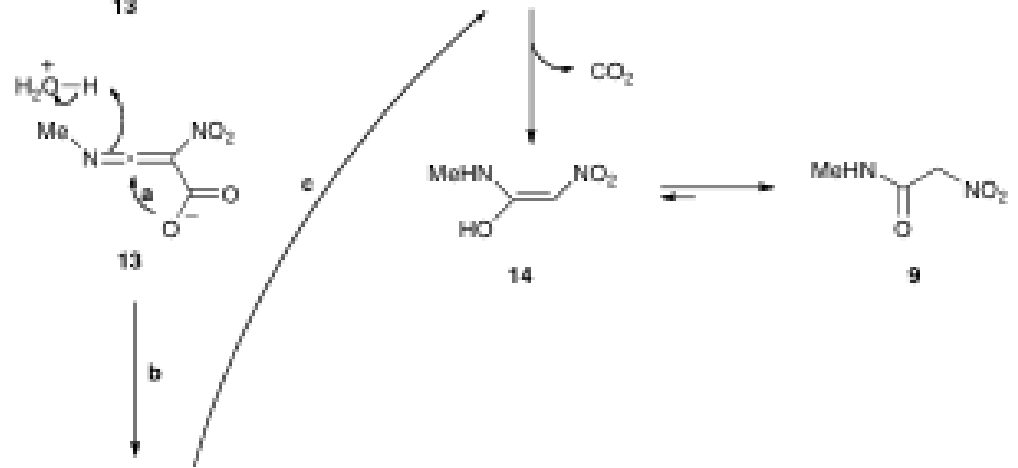<smiles>CNC1(CO)OC(=O)C1[N+](=O)[O-]</smiles>

15<smiles>CNc1cc([N+](=O)[O-])c(CC(=O)O)o1</smiles>

15<smiles>C1CC[Tl]CC1</smiles>

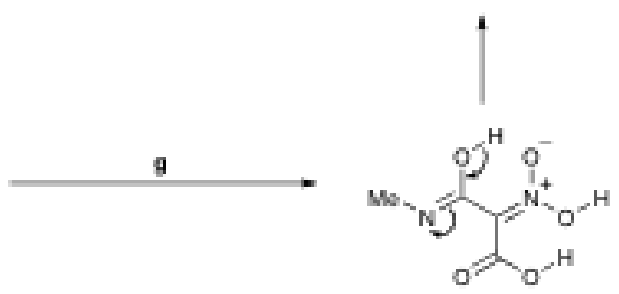


Compound $\mathbf{1 5}$ is expected to be highly reactive and hence reacts readily with water. When the enamine moiety is attacked by water (route c), the resulting intermediate is $\mathbf{1 4}$, which tautomerizes to nitroacetamide $\mathbf{9}$. On the other hand, 5 when water attacks the carbonyl group of $\mathbf{1 5}$ (route d), nitromalonic acid monoamide $\mathbf{1 7}$ is formed which readily undergoes dehydration and decarboxylation in a concerted manner to afford nitrile oxide $\mathbf{2 d}$. Another possibility is that 15 may undergo prototropic rearrangement to form the less10 strained intermediate $\mathbf{1 6}$ (route e), the two electrophilic carbons in which are attacked by water to give the nitromalonic acid derivative $\mathbf{1 7}$ (route $\mathbf{f}$ or $\mathbf{g}$ ). In the present mechanism, nitroenamine $\mathbf{1 4}$ and nitromalonic acid derivative $\mathbf{1 7}$ are considered the key intermediates. This consideration is 15 supported by the experimental fact that methanolysis of isoxazolone 5a affords a mixture of methoxynitroenamine $\mathbf{1 8}$ and a small amount of nitromalonic acid amide ester 3d, which are corresponding to hydroxy derivatives $\mathbf{1 4}$ and 17, respectively (Scheme 6).

20

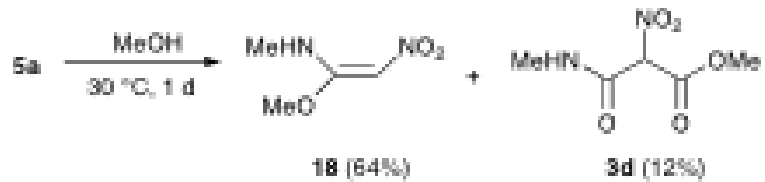

Scheme 6. Methanolysis of nitroisoxazolone 5a.

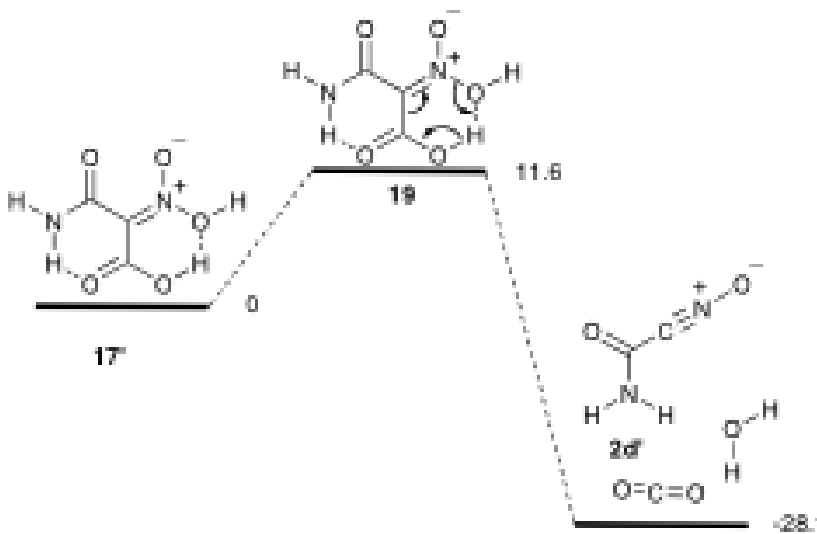

Scheme 7. Relative energies ( $\mathrm{kcal} / \mathrm{mol}$ ) for the formation of 2d' from 17' via transition state 19 with simultaneous decarboxylation and dehydration.

25

Nitroacetates can be used as the precursors of nitrile oxide 1, which has an ester function; however, dehydrating agents and severe conditions need to be employed for this 30 conversion. ${ }^{6-9}$ Indeed, nitroacetamide 9, the tautomer of hydroxynitroenamine $\mathbf{1 4}$, is not converted to nitrile oxide $\mathbf{2 d}$ upon treatment with an acetonitrile/water $(3 / 1, v / v)$ mixture alone. Hence, the precursor of $\mathbf{2 d}$ is thought to be nitromalonic acid derivative $\mathbf{1 7}$ and not nitroenamine 14. As 35 shown in Scheme 1, the nitromalonic acid amide ester 3a serves as the precursor of nitrile oxide 2a under severe reaction conditions. ${ }^{10}$ In contrast, our method efficiently generates nitrile oxide $\mathbf{2 d}$ at room temperature even when no special reagent is employed; the carbamoyl group of $\mathbf{1 6}$ is 40 thought to play an important role in dehydration as well as decarboxylation.

Theoretical calculations were performed to investigate the plausible reaction pathway by using a simplified model compound nitromalonic acid monoamide 17', which is 45 converted to carbamoylnitrile oxide 2d'. For this purpose, the DFT method based on Becke's nonlocal three-parameter hybrid functional is employed in combination with the Lee, Yang, and Parr correlation functional (B3LYP). A split valence double- $\zeta$ basis set with extra polarization and diffuse 50 functions $\left(6-31+G^{* *}\right)$ is used. Model compound 17' has ten conformers, each with two or three intramolecular hydrogen bonds. Among them, one conformer 17' nicely leads to 2d' via transition state 19; the activation energy in this case is $11.6 \mathrm{kcal} / \mathrm{mol}$, as shown in Scheme 7 and Figure 2. The 55 interatomic distance ( $2.68 \AA$ ) between $\mathrm{N} 1$ of the carbamoyl group and $\mathrm{O} 5$ of the carboxyl group in $\mathbf{1 9}$ clearly indicates the existence of strong intramolecular hydrogen bonding in this compound even in the transition state; this hydrogen bonding is responsible for the planar geometry of the transition state. 60 The generation of $\mathbf{2 d}$ from $\mathbf{1 7}$ under the quite mild conditions can be ascribed to the planarity of the transition state, which favors concerted decarboxylation and dehydration.

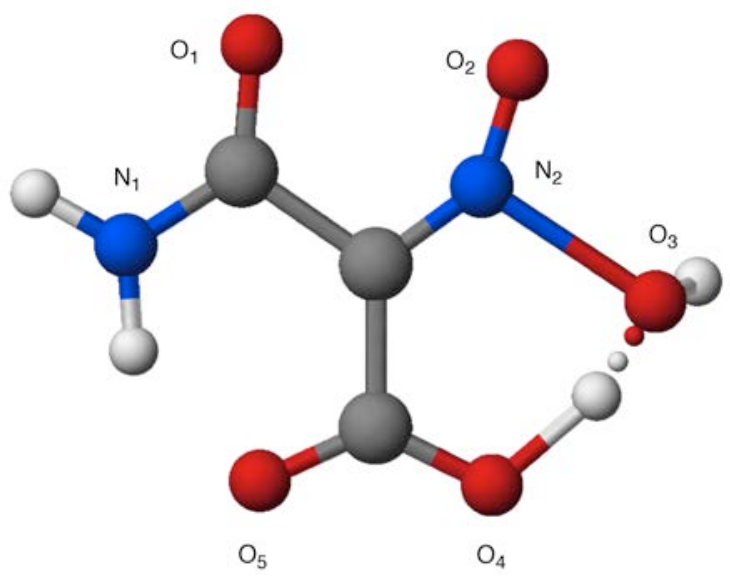

Figure 2. Calculated geometry of transition state $\mathbf{1 9}$.

\section{Conclusions}

Nitroisoxazolone 5a serves as the precursor of nitrile oxide 2d, which has a carbamoyl group and undergoes cycloaddition with various dipolarophiles at $30{ }^{\circ} \mathrm{C}$ to afford functionalized 70 isoxazol(in)es $\mathbf{8}$ and $\mathbf{1 1}$ in good yield. In the present method, only water is required for the generation of $\mathbf{2 d}$, while other methods for synthesizing nitrile oxides require the use of special generators such as bases, oxidants, and dehydrating agents. Moreover, the present reaction can be conducted in air 75 with simple experimental manipulations. These advantages make the proposed method a very useful tool in organic syntheses. 
A plausible mechanism for this reaction is also proposed. According to this mechanism, nitromalonic acid monoamide $\mathbf{1 7}$ is the precursor of nitrile oxide $\mathbf{2 d}$; this assumption is well supported by the results of DFT calculations performed using B BLYP/6-31+G**. The calculation result also indicates that the carbamoyl group takes part in the concerted decarboxylation and dehydration assisted by intramolecular hydrogen bonding. This concerted reaction enables the easy formation of nitrile oxide $\mathbf{2 d}$ even under mild conditions.

\section{${ }_{10}$ Experimental}

\section{General}

The melting points were determined on a Yanaco micromelting- points apparatus, and were uncorrected. All the reagents and solvents were commercially available and used 15 as received. The ${ }^{1} \mathrm{H}$ NMR spectra were measured on a Bruker DPX-400 or Varian UNITY INOVA 400 at $400 \mathrm{MHz}$ with TMS as an internal standard. The ${ }^{13} \mathrm{C}$ NMR spectra were measured on a Bruker DPX-400 or Varian UNITY INOVA 400 at $100 \mathrm{MHz}$, and assignments of ${ }^{13} \mathrm{C}$ NMR spectra were 20 performed by DEPT experiments. The IR spectra were recorded on a Horiba FT-200 IR spectrometer and a JASCO FT/IR- 4200 Spectrophotometer. The mass spectra were recorded on a JEOL JMS-AX505HA. The high resolution mass spectra were measured on a JEOL JMS-700 MStation.

25 The elemental microanalyses were performed using a Yanaco MT-3 CHN corder.

\section{2-Methyl-4-nitro-3-isoxazolin-5(2H)-one}

(5a).

Nitroisoxazolone 5a was easily prepared from commercially 30 available ethyl nitroacetate by three steps with simple experimental manipulations; 1) condensation of nitroacetate with orthoformate, 2) condensation with hydroxylamine, and 3) $\mathrm{N}$-methylation with dimethyl sulfate (Details are given in Electronic Supplementary Information). ${ }^{20}$

35 3,4-Bis( $N$-methylcarbamoyl)-1,2,5-oxadiazole 2-Oxide (Furoxan) (6). ${ }^{8 a, 23}$ A solution of nitroisoxazolone 5a (72 mg, $0.50 \mathrm{mmol})$ in water $(5.0 \mathrm{~mL})$ was stirred at $30{ }^{\circ} \mathrm{C}$ for 1 day. When the solvent was removed under reduced pressure, a colorless crystalline product was obtained which contained 40 furoxan. Further purification was performed by recrystallization from benzene to give 6 (40 mg, $0.20 \mathrm{mmol}$, yield $80 \%$ based on 5a). Mp 168-169 ${ }^{\circ} \mathrm{C}$ (lit. ${ }^{8 \mathrm{a}} 163-165{ }^{\circ} \mathrm{C}$ ). IR (KBr) 3323, 1695, 1653, $1460 \mathrm{~cm}^{-1} ;{ }^{1} \mathrm{H}$ NMR (400 MHz, $\left.\mathrm{CDCl}_{3}\right) \delta 3.05(\mathrm{~d}, J=4.8 \mathrm{~Hz}, 3 \mathrm{H}), 3.06(\mathrm{~d}, J=4.8 \mathrm{~Hz}, 3 \mathrm{H})$, ${ }_{45}$ 8.5-8.7 (br, 1H), 9.6-9.8 (br, $\left.1 \mathrm{H}\right) ;{ }^{1} \mathrm{H}$ NMR (400 MHz, DMSO $\left.-d_{6}\right) \delta 2.63$ (d, $\left.J=4.8 \mathrm{~Hz}, 3 \mathrm{H}\right), 2.65(\mathrm{~d}, J=4.8 \mathrm{~Hz}, 3 \mathrm{H})$, 8.7-8.9 (br, 1H), 9.1-9.2 (br, $1 \mathrm{H})$; ${ }^{13} \mathrm{C}$ NMR (100 MHz, DMSO- $\left.d_{6}\right) \delta 26.3\left(\mathrm{CH}_{3}\right), 26.4\left(\mathrm{CH}_{3}\right), 110.3(\mathrm{C}), 151.7(\mathrm{C})$, 154.3 (C), 156.7 (C); MS (EI) 170 (8), 143 (73), 113 (32), 58 50 (100), 53 (62). Anal. Calcd for $\mathrm{C}_{6} \mathrm{H}_{8} \mathrm{~N}_{4} \mathrm{O}_{4}$ : C, 36.00; H, 4.03; N, 27.99\%. Found: C, 36.19; H, 4.01; N, 28.26\%.

\section{Cycloaddition of Nitrile Oxide with Dipolarophiles General Procedure}

55 To a solution of nitroisoxazolone 5 a $(86 \mathrm{mg}, 0.60 \mathrm{mmol})$ and dipolarophile 7 or 10 (3.0 mmol) in acetonitrile $(4.5 \mathrm{~mL})$, water $(1.5 \mathrm{~mL})$ was added, and the resultant mixture was stirred at $30{ }^{\circ} \mathrm{C}$ for 1 day. After removal of the solvent under reduced pressure, the residue was subjected to column 60 chromatography on silica gel or recrystallization to isolate cycloadduct $\mathbf{8}$ or $\mathbf{1 1}$.

3-( $N$-Methylcarbamoyl)-5-phenylisoxazole (8a). ${ }^{12,23}$ Eluted with hexane/AcOEt (80/20). Pale yellow plates. Mp 199$200{ }^{\circ} \mathrm{C}$ (lit. ${ }^{12 \mathrm{c}} 198-199^{\circ} \mathrm{C}$ ). IR (KBr) 3327, $1668 \mathrm{~cm}^{-1} ;{ }^{1} \mathrm{H}$ ${ }_{65} \mathrm{NMR}\left(400 \mathrm{MHz}, \mathrm{CDCl}_{3}\right.$ ) $\delta 3.04(\mathrm{~d}, J=5.0 \mathrm{~Hz}, 3 \mathrm{H}), 6.8-6.9$ (br, 1H), 6.97 (s, 1H), 7.46-7.51 (m, 3H), 7.78-7.81 (m, 2H); ${ }^{13} \mathrm{C}$ NMR $\left(100 \mathrm{MHz}, \mathrm{CDCl}_{3}\right) \delta 26.4\left(\mathrm{CH}_{3}\right), 99.3(\mathrm{CH}), 125.9$ (CH), 126.7 (C), $129.1(\mathrm{CH}), 130.7$ (CH), 159.1 (C), 159.5 (C), 171.5 (C); MS (EI) 202 (M+, 9), 105 (31), 58 (100). Anal. ${ }_{70}$ Calcd for $\mathrm{C}_{11} \mathrm{H}_{10} \mathrm{~N}_{2} \mathrm{O}_{2}$ : C, 65.33; H, 4.98; N, 13.86\%. Found: C, 65.36; H, 5.01; N, 13.88\%.

5-Hydroxymethyl-3-( $N$-methylcarbamoyl)isoxazole (8b). Eluted with hexane/AcOEt (80/20). Colorless plates. Mp 96$97{ }^{\circ} \mathrm{C}$. IR (KBr) 3600-3100 (br), $1671 \mathrm{~cm}^{-1}$; ${ }^{1} \mathrm{H}$ NMR (400 $\left.75 \mathrm{MHz}, \mathrm{CDCl}_{3}\right) \delta$ 2.3-2.6 (br, $\left.1 \mathrm{H}\right), 3.00(\mathrm{~d}, J=5.2 \mathrm{~Hz}, 3 \mathrm{H})$, 4.81 (br s, 2H), 6.69 (s, 1H), 6.7-6.9 (br, 1H); ${ }^{1} \mathrm{H}$ NMR (400 MHz, DMSO- $\left.d_{6}\right) \delta 2.75$ (d, $J=5.2 \mathrm{~Hz}, 3 \mathrm{H}$ ), 4.60 (dd, $J=6.0$, $0.8 \mathrm{~Hz}, 2 \mathrm{H}), 5.73(\mathrm{t}, J=6.0 \mathrm{~Hz}, 1 \mathrm{H}), 6.63(\mathrm{~d}, J=0.8 \mathrm{~Hz}, 1 \mathrm{H})$, 8.6-8.7 (br, $1 \mathrm{H}) ;{ }^{13} \mathrm{C}$ NMR (100 MHz, DMSO-d $\left.{ }_{6}\right) \delta 26.0$ $80\left(\mathrm{CH}_{3}\right), 54.8\left(\mathrm{CH}_{2}\right), 101.2(\mathrm{CH}), 158.8(\mathrm{C}), 159.1(\mathrm{C}), 174.6$ (C); MS (EI) 156 (3), 125 (11), 68 (25), 58 (100). HRMS Calcd for $\mathrm{C}_{6} \mathrm{H}_{8} \mathrm{~N}_{2} \mathrm{O}_{3}$ : 156.0535. Found: 156.0535 .

5-Bromomethyl-3-( $N$-methylcarbamoyl)isoxazole (8c). Eluted with hexane/AcOEt (80/20). Colorless plates. Mp 133$85134{ }^{\circ} \mathrm{C}$. IR $(\mathrm{KBr})$ 3343, $1671 \mathrm{~cm}^{-1} ;{ }^{1} \mathrm{H}$ NMR $(400 \mathrm{MHz}$, $\left.\mathrm{CDCl}_{3}\right) \delta 3.00(\mathrm{~d}, J=4.8 \mathrm{~Hz}, 3 \mathrm{H}), 4.48(\mathrm{~s}, 2 \mathrm{H}), 6.76(\mathrm{~s}, 1 \mathrm{H})$, 6.7-6.9 (br, $1 \mathrm{H}) ;{ }^{13} \mathrm{C}$ NMR $\left(100 \mathrm{MHz}, \mathrm{CDCl}_{3}\right) \delta 18.0\left(\mathrm{CH}_{2}\right)$, $26.1\left(\mathrm{CH}_{3}\right), 103.5(\mathrm{CH}), 158.8(\mathrm{C}), 158.9(\mathrm{C}), 169.0(\mathrm{C})$; MS (EI) $220\left(\mathrm{M}^{+}, 1\right), 125$ (17), 68 (14), 58 (100). Anal. Calcd for ${ }_{90} \mathrm{C}_{6} \mathrm{H}_{7} \mathrm{~N}_{2} \mathrm{O}_{2} \mathrm{Br}$ : C, 32.90; H, 3.22; N, 12.79\%. Found: C, 32.83; $\mathrm{H}, 3.22$; N, $12.82 \%$.

\section{4,5-Bis(ethoxycarbonyl)-3-( $N$-methylcarbamoyl)isoxazole}

(8d). Eluted with hexane/AcOEt (80/20). Cololess plates. Mp 116-118 ${ }^{\circ} \mathrm{C}$. IR (neat) 3300, 1732, $1670 \mathrm{~cm}^{-1}$; ${ }^{1} \mathrm{H}$ NMR (400 $\left.{ }_{95} \mathrm{MHz}_{\mathrm{CDCl}}\right) \delta 1.400(\mathrm{t}, J=7.2 \mathrm{~Hz}, 3 \mathrm{H}), 1.404(\mathrm{t}, J=7.2 \mathrm{~Hz}$, $3 \mathrm{H}), 3.02$ (d, $J=5.2 \mathrm{~Hz}, 3 \mathrm{H}), 4.45$ (q, $J=7.2 \mathrm{~Hz}, 2 \mathrm{H}), 4.46$ (q, $J=7.2 \mathrm{~Hz}, 2 \mathrm{H}), 6.8-6.9(\mathrm{br}, 1 \mathrm{H}) ;{ }^{13} \mathrm{C}$ NMR $(100 \mathrm{MHz}$, $\left.\mathrm{CDCl}_{3}\right) \delta 13.82\left(\mathrm{CH}_{3}\right), 13.84\left(\mathrm{CH}_{3}\right), 26.2\left(\mathrm{CH}_{3}\right), 62.7\left(\mathrm{CH}_{2}\right)$, $63.0\left(\mathrm{CH}_{2}\right), 117.3(\mathrm{C}), 155.2$ (C), 156.2 (C), 157.3 (C), 158.7 100 (C), 160.3 (C); MS (EI) 225 (2), 197 (6), 140 (9), 112 (11), 68 (18), 58 (100). Anal. Calcd for $\mathrm{C}_{11} \mathrm{H}_{14} \mathrm{~N}_{2} \mathrm{O}_{6}$ : C, 48.89; $\mathrm{H}, 5.22$; N, 10.37\%. Found: C, 48.87; H, 5.24; N, 10.41\%.

4,5-Dihydro-3-( $N$-methylcarbamoyl)-5-phenylisoxazole (11a). ${ }^{12}$ Recrystallized from a mixed solvent of benzene and 105 hexane (1/1). Colorless solid. Mp 113-115 ${ }^{\circ} \mathrm{C}$ (lit. $\left.{ }^{12 \mathrm{c}} 111^{\circ} \mathrm{C}\right)$. IR (KBr) 3287, 1655, $1544 \mathrm{~cm}^{-1}$; ${ }^{1} \mathrm{H}$ NMR (400 MHz, $\mathrm{CDCl}_{3}$ ) $\delta 2.94(\mathrm{~d}, J=5.1 \mathrm{~Hz}, 3 \mathrm{H}), 3.27$ (dd, $J=17.9,8.8 \mathrm{~Hz}, 1 \mathrm{H})$, 3.66 (dd, $J=17.9,11.5 \mathrm{~Hz}, 1 \mathrm{H}$ ), 5.74 (dd, $J=11.5,8.8 \mathrm{~Hz}$, 1H), 6.6-6.8 (br, 1H), 7.3-7.45 (m, 5H); ${ }^{13} \mathrm{C}$ NMR (100 MHz, $\left.{ }_{110} \mathrm{CDCl}_{3}\right) \delta 26.1\left(\mathrm{CH}_{3}\right), 41.2\left(\mathrm{CH}_{2}\right), 84.6(\mathrm{CH}), 125.9(\mathrm{CH})$, $128.6(\mathrm{CH}), 128.8(\mathrm{CH}), 139.6(\mathrm{C}), 153.6(\mathrm{C}), 160.2(\mathrm{C})$; MS (FAB) $205\left(\mathrm{M}^{+}+1,92\right), 107$ (100), 105 (92). HRMS Calcd for $\mathrm{C}_{11} \mathrm{H}_{12} \mathrm{~N}_{2} \mathrm{O}_{2}$ : 204.0899. Found: 204.0899.

4,5-Dihydro-3-( $N$-methylcarbamoyl)-5-propylisoxazole 115 (11b). Eluted with hexane/AcOEt (50/50). Colorless solid. Mp 
60-62 ${ }^{\circ} \mathrm{C}$. IR (KBr) 3297, 1656, $1551 \mathrm{~cm}^{-1} ;{ }^{1} \mathrm{H}$ NMR (400 $\left.\mathrm{MHz}, \mathrm{CDCl}_{3}\right) \delta 0.93(\mathrm{t}, J=7.2 \mathrm{~Hz}, 3 \mathrm{H}), 1.3-1.45(\mathrm{~m}, 2 \mathrm{H})$, 1.5-1.6 (m, 1H), 1.65-1.75 (m, 1H), 2.85 (dd, $J=17.6,8.4 \mathrm{~Hz}$, $1 \mathrm{H}), 2.89$ (d, $J=4.8 \mathrm{~Hz}, 3 \mathrm{H}), 3.25$ (dd, $J=17.6,10.8 \mathrm{~Hz}, 1 \mathrm{H}$ ), 54.75 (dddd, $J=10.8,8.4,6.8,5.6 \mathrm{~Hz}, 1 \mathrm{H}$ ), 6.6-6.8 (br, $1 \mathrm{H}$ ); ${ }^{13} \mathrm{C} \mathrm{NMR}\left(100 \mathrm{MHz}, \mathrm{CDCl}_{3}\right) \delta 13.8\left(\mathrm{CH}_{3}\right), 18.5\left(\mathrm{CH}_{2}\right), 26.1$ $\left(\mathrm{CH}_{3}\right), 37.2\left(\mathrm{CH}_{2}\right), 38.3\left(\mathrm{CH}_{2}\right), 83.6(\mathrm{CH}), 153.8(\mathrm{C}), 160.6$ (C); MS (FAB) $171\left(\mathrm{M}^{+}+1,100\right)$. HRMS Calcd for $\mathrm{C}_{8} \mathrm{H}_{14} \mathrm{~N}_{2} \mathrm{O}_{2}$ : 170.1055. Found: 170.1056 .

10 3-( $N$-Methylcarbamoyl)-3a,5,6,6a-tetrahydro-4H-

cyclopent $[\boldsymbol{d}]$ isoxazole (11c). Eluted with hexane/AcOEt (50/50). Colorless solid. Mp 72-75 ${ }^{\circ} \mathrm{C}$. IR (KBr) 3330, 1655 $\mathrm{cm}^{-1}$; ${ }^{1} \mathrm{H}$ NMR $\left(400 \mathrm{MHz}, \mathrm{CDCl}_{3}\right) \delta 1.3-1.45$ (m, 1H), 1.651.85 (m, 3H), 2.05-2.15 (m, 2H), 2.89 (d, $J=5.2 \mathrm{~Hz}, 3 \mathrm{H})$, 153.92 (dd, $J=8.8,8.8 \mathrm{~Hz}, 1 \mathrm{H}$ ), 5.20 (dd, $J=8.8,4.8 \mathrm{~Hz}, 1 \mathrm{H}$ ), 6.5-6.7 (br, 1H); ${ }^{13} \mathrm{C}$ NMR (100 MHz, $\left.\mathrm{CDCl}_{3}\right) \delta 23.2\left(\mathrm{CH}_{2}\right)$, $26.0\left(\mathrm{CH}_{3}\right), 31.5\left(\mathrm{CH}_{2}\right), 35.7\left(\mathrm{CH}_{2}\right), 51.0(\mathrm{CH}), 89.8(\mathrm{CH})$, 155.4 (C), 160.5 (C); MS (FAB) $169\left(\mathrm{M}^{+}+1,100\right)$. Anal. Calcd for $\mathrm{C}_{8} \mathrm{H}_{12} \mathrm{~N}_{2} \mathrm{O}_{2}$ : C, 57.13; $\mathrm{H}, 7.19 ; \mathrm{N}, 16.66 \%$. Found: C, 20 56.95; H, 7.08; N, 16.37\%.

4,5-Dihydro-5-hydroxymethyl-3- $(N$ -

methylcarbamoyl)isoxazole (11d). Recrystallized from benzene. Colorless plates. Mp 85-86 ${ }^{\circ} \mathrm{C}$. IR (KBr) 3500-3200 (br), 1654, $1558 \mathrm{~cm}^{-1}$; ${ }^{1} \mathrm{H}$ NMR (400 MHz, $\left.\mathrm{CDCl}_{3}\right) \delta 1.6-2.0$ 25 (br, $1 \mathrm{H}$ ), 2.92 (d, $J=5.2 \mathrm{~Hz}, 3 \mathrm{H}$ ), 3.15 (dd, $J=18.0,8.0 \mathrm{~Hz}$, 1H), 3.28 (dd, $J=18.0,11.2 \mathrm{~Hz}, 1 \mathrm{H}$ ), 3.65 (dd, $J=12.4,4.4$ $\mathrm{Hz}, 1 \mathrm{H}$ ), 3.84 (dd, $J=12.4,3.2 \mathrm{~Hz}, 1 \mathrm{H}$ ), 4.88 (dddd, $J=11.2$, 8.0, 4.4, 3.2 Hz, 1H), 6.4-6.8 (br, $1 \mathrm{H}) ;{ }^{13} \mathrm{C}$ NMR (100 MHz, $\left.\mathrm{CDCl}_{3}\right) \delta 26.1\left(\mathrm{CH}_{3}\right), 34.8\left(\mathrm{CH}_{2}\right), 63.3\left(\mathrm{CH}_{2}\right), 83.5(\mathrm{CH})$, 30154.5 (C), 159.1 (C), 160.3 (C); MS (EI) 158 (M+, 1), 85 (10), 58 (100). HRMS Calcd for $\mathrm{C}_{6} \mathrm{H}_{10} \mathrm{~N}_{2} \mathrm{O}_{3}$ : 158.1522. Found: 158.1528.

4,5-Dihydro-5-ethoxymethyl-3-( $N$ -

methylcarbamoyl)isoxazole (11e). Eluted with AcOEt. 35 Colorless granules. Mp 43-44 ${ }^{\circ} \mathrm{C}$. IR (KBr) 3336, 1663, 1543 $\mathrm{cm}^{-1}$; ${ }^{1} \mathrm{H}$ NMR (400 MHz, $\left.\mathrm{CDCl}_{3}\right) \delta 1.20(\mathrm{t}, J=7.0 \mathrm{~Hz}, 3 \mathrm{H})$, 2.91 (d, $J=5.0 \mathrm{~Hz}, 3 \mathrm{H}$ ), 3.13 (dd, $J=17.8,8.0 \mathrm{~Hz}, 1 \mathrm{H}$ ), 3.26 (dd, $J=17.8,11.1 \mathrm{~Hz}, 1 \mathrm{H}), 3.55$ (d, $J=4.7 \mathrm{~Hz}, 2 \mathrm{H}), 3.55$ (q, $J=7.0 \mathrm{~Hz}, 2 \mathrm{H}), 4.8-4.95(\mathrm{~m}, 1 \mathrm{H}), 6.65-6.8(\mathrm{br}, 1 \mathrm{H}) ;{ }^{13} \mathrm{C}$ 40 NMR (100 MHz, $\left.\mathrm{CDCl}_{3}\right) \delta 15.4\left(\mathrm{CH}_{3}\right), 26.4\left(\mathrm{CH}_{3}\right), 35.9$ $\left(\mathrm{CH}_{2}\right), 67.5\left(\mathrm{CH}_{2}\right), 71.4\left(\mathrm{CH}_{2}\right), 82.5(\mathrm{CH}), 154.3(\mathrm{C}), 160.7$ (C); MS (FAB) $187\left(\mathrm{M}^{+}+1,100\right)$. HRMS Calcd for $\mathrm{C}_{8} \mathrm{H}_{14} \mathrm{~N}_{2} \mathrm{O}_{3}$ : 186.1004. Found: 186.1004 .

5-Acetylaminomethyl-4,5-dihydro-3- $(N$ -

45 methylcarbamoyl)isoxazole (11g). Recrystallized from chloroform. White solid. Mp 169-171 ${ }^{\circ} \mathrm{C}$. IR (KBr) 3308, 1655 (with shoulder), $1597 \mathrm{~cm}^{-1}$; ${ }^{1} \mathrm{H}$ NMR (400 $\mathrm{MHz} \mathrm{CDCl}_{3}$ ) $\delta 1.82$ (s, 3H), 2.67 (d, $J=4.7 \mathrm{~Hz}, 3 \mathrm{H}), 2.91$ (dd, $J=17.9,7.6$ $\mathrm{Hz}, 1 \mathrm{H}$ ), 3.20 (dd, $J=17.9,10.9 \mathrm{~Hz}, 1 \mathrm{H}$ ), 3.22 (dd, $J=5.7$, $505.6 \mathrm{~Hz}, 2 \mathrm{H}$ ), 4.72 (ddt, $J=10.9,7.6,5.6 \mathrm{~Hz}, 1 \mathrm{H}$ ), 8.12 (br t, $J$ $=5.7 \mathrm{~Hz}, 1 \mathrm{H}), 8.38$ (br q, $J=4.7 \mathrm{~Hz}, 1 \mathrm{H}) ;{ }^{13} \mathrm{C}$ NMR $(100$ $\left.\mathrm{MHz}, \mathrm{CDCl}_{3}\right) \delta 23.3\left(\mathrm{CH}_{3}\right), 26.6\left(\mathrm{CH}_{3}\right), 37.5\left(\mathrm{CH}_{2}\right), 42.4$ $\left(\mathrm{CH}_{2}\right), 81.5(\mathrm{CH}), 155.0(\mathrm{C}), 160.6$ (C), 170.6 (C); MS (FAB) $200\left(\mathrm{M}^{+}+1,100\right)$. HRMS Calcd for $\mathrm{C}_{8} \mathrm{H}_{13} \mathrm{~N}_{3} \mathrm{O}_{3}$ : 199.0957 . 55 Found: 199.0959 .

4,5-Dihydro-5-ethoxy-3-( $N$-methylcarbamoyl)isoxazole

(11h). Eluted with hexane/AcOEt (50/50). Orange plates. Mp 99-101 ${ }^{\circ} \mathrm{C}$. IR (KBr) 3305, 1655, $1090 \mathrm{~cm}^{-1}$; ${ }^{1} \mathrm{H}$ NMR (400
$\mathrm{MHz}, \mathrm{CDCl}_{3}$ ) $\delta 1.22(\mathrm{dd}, J=7.2,7.2 \mathrm{~Hz}, 3 \mathrm{H}$ ), 2.93 (d, $J=4.8$ $60 \mathrm{~Hz}, 3 \mathrm{H}$ ), 3.13 (dd, $J=18.8,2.4 \mathrm{~Hz}, 1 \mathrm{H}$ ), 3.26 (dd, $J=18.8$, $6.8 \mathrm{~Hz}, 1 \mathrm{H}), 3.60$ (dq, $J=9.2,7.2 \mathrm{~Hz}, 1 \mathrm{H}), 3.87$ (dq, $J=9.2$, $7.2 \mathrm{~Hz}, 1 \mathrm{H}$ ), 5.67 (dd, J = 6.8, 2.4 Hz, 1H), 6.6-6.7 (br, 1H); ${ }^{13} \mathrm{C} \mathrm{NMR}\left(100 \mathrm{MHz}, \mathrm{CDCl}_{3}\right) \delta 15.0\left(\mathrm{CH}_{3}\right), 26.1\left(\mathrm{CH}_{3}\right), 40.1$ $\left(\mathrm{CH}_{2}\right), 64.3\left(\mathrm{CH}_{2}\right), 104.9(\mathrm{CH}), 154.3(\mathrm{C}), 159.9(\mathrm{C})$; MS 65 (FAB) $173\left(\mathrm{M}^{+}+1,96\right), 127$ (100). Anal. Calcd for $\mathrm{C}_{7} \mathrm{H}_{12} \mathrm{~N}_{2} \mathrm{O}_{3}$ : C, 48.83; H, 7.02; N, 16.27\%. Found: C, 48.70; H, $6.84 ; \mathrm{N}, 16.45 \%$.

3-(N-Methylcarbamoyl)-3a,4,5,6a-tetrahydrofuro[3,2-

d]isoxazole (11i). Recrystallized from a mixed solvent of 70 benzene and hexane (1/1). Colorless solid. Mp 138-139 ${ }^{\circ} \mathrm{C}$. IR (KBr) 3329, 1662, 1557, $1091 \mathrm{~cm}^{-1}$; ${ }^{1} \mathrm{H}$ NMR $(400 \mathrm{MHz}$, $\mathrm{CDCl}_{3}$ ) $\delta 2.22$ (dddd, $J=8.9,8.3,5.1,5.0 \mathrm{~Hz}, 1 \mathrm{H}$ ), 2.40 (dd, $J=13.1,5.0 \mathrm{~Hz}, 1 \mathrm{H}), 2.92$ (d, $J=5.0 \mathrm{~Hz}, 3 \mathrm{H}), 3.54$ (ddd, $J=$ 13.1, 8.9, $5.1 \mathrm{~Hz}, 1 \mathrm{H}$ ), 4.04 (dd, $J=8.9,6.2 \mathrm{~Hz}, 1 \mathrm{H}$ ), 4.10 (dd, $75 J=8.9,8.3 \mathrm{~Hz}, 1 \mathrm{H}), 6.27$ (d, $J=6.2 \mathrm{~Hz}, 1 \mathrm{H}), 6.7-6.9$ (br, $1 \mathrm{H}) ;{ }^{13} \mathrm{C}$ NMR $\left(100 \mathrm{MHz}, \mathrm{CDCl}_{3}\right) \delta 26.1\left(\mathrm{CH}_{3}\right), 29.7\left(\mathrm{CH}_{2}\right)$, $50.8(\mathrm{CH}), 67.0\left(\mathrm{CH}_{2}\right), 110.6(\mathrm{CH}), 154.2(\mathrm{C}), 160.0(\mathrm{C}) ; \mathrm{MS}$ (FAB) $171\left(\mathrm{M}^{+}+1,100\right)$. Anal. Calcd for $\mathrm{C}_{7} \mathrm{H}_{10} \mathrm{~N}_{2} \mathrm{O}_{3}$ : C, 49.40; H, 5.92; N, 16.47\%. Found: C, 49.26; H, 5.96; N, $8016.53 \%$.

4,5-Dihydro-5-ethoxycarbonyl-3- $(N$ -

methylcarbamoyl)isoxazole (11j). Eluted with hexane/AcOEt (50/50). Pale yellow oil. IR (neat) 3337, 1747, 1666, $1556 \mathrm{~cm}^{-1}$; ${ }^{1} \mathrm{H}$ NMR (400 MHz, $\left.\mathrm{CDCl}_{3}\right) \delta 1.23(\mathrm{t}, J=$ $857.1 \mathrm{~Hz}, 3 \mathrm{H}$ ), 2.68 (d, $J=4.7 \mathrm{~Hz}, 3 \mathrm{H}$ ), 3.34 (dd, $J=17.9,6.9$ $\mathrm{Hz}, 1 \mathrm{H}$ ), 3.52 (dd, $J=17.9,12.1 \mathrm{~Hz}, 1 \mathrm{H}), 4.16$ (q, $J=7.1 \mathrm{~Hz}$, $2 \mathrm{H}$ ), 5.23 (dd, $J=12.1,6.9 \mathrm{~Hz}, 1 \mathrm{H}), 8.45-8.5$ (br, $1 \mathrm{H}) ;{ }^{13} \mathrm{C}$ NMR (100 MHz, $\left.\mathrm{CDCl}_{3}\right) \delta 14.1\left(\mathrm{CH}_{3}\right), 26.2\left(\mathrm{CH}_{3}\right), 38.0$ $\left(\mathrm{CH}_{2}\right), 62.2\left(\mathrm{CH}_{2}\right), 79.3(\mathrm{CH}), 153.5(\mathrm{C}), 159.5(\mathrm{C}), 169.3$ 90 (C); MS (FAB) $187\left(\mathrm{M}^{+}+1,100\right)$. HRMS Calcd for $\mathrm{C}_{8} \mathrm{H}_{12} \mathrm{~N}_{2} \mathrm{O}_{4}$ : 200.0797. Found: 200.0799.

4,5-Bis(methoxycarbonyl)-4,5-dihydro-3-( $N$ -

methylcarbamoyl)isoxazole (11k). Eluted with hexane/AcOEt (20/80). Colorless oil. IR (neat) 3375, 1746, 95 1674, $1558 \mathrm{~cm}^{-1} ;{ }^{1} \mathrm{H}$ NMR (400 MHz, $\mathrm{CDCl}_{3}$ ) cis/trans = 93/7, cis-isomer $\delta 2.93(\mathrm{~d}, J=5.2 \mathrm{~Hz}, 3 \mathrm{H}), 3.82(\mathrm{~s}, 3 \mathrm{H}), 3.84$ (s, $3 \mathrm{H}), 4.69$ (d, $J=6.4 \mathrm{~Hz}, 1 \mathrm{H}), 5.33$ (d, $J=6.4 \mathrm{~Hz}, 1 \mathrm{H}), 6.5-$ $6.7(\mathrm{br}, 1 \mathrm{H})$, trans-isomer $\delta 2.92$ (partially overlapped with a signal of cis-isomer), 3.76 (s, 3H), 3.79 (s, 3H), 4.72 (d, $J=$ $10012.0 \mathrm{~Hz}, 1 \mathrm{H}), 5.38$ (d, $J=12.0 \mathrm{~Hz}, 1 \mathrm{H}) ;{ }^{13} \mathrm{C} \mathrm{NMR}(100 \mathrm{MHz}$, $\left.\mathrm{CDCl}_{3}\right) \delta 26.1\left(\mathrm{CH}_{3}\right), 53.2\left(\mathrm{CH}_{3}\right), 53.4\left(\mathrm{CH}_{3}\right), 55.4(\mathrm{CH}), 83.0$ (CH), 151.3 (C), 158.3 (C), 167.9 (C), 168.0 (C); MS (FAB) $245\left(\mathrm{M}^{+}+1,100\right)$. HRMS Calcd for $\mathrm{C}_{9} \mathrm{H}_{12} \mathrm{~N}_{2} \mathrm{O}_{6}$ : 244.0695 . Found: 244.0694 .

105 5-Acetyl-4,5-dihydro-3-( $N$-methylcarbamoyl)isoxazole (11). Recrystallized from a mixed solvent of benzene and hexane (1/1). Pale yellow solid. Mp 106-108 ${ }^{\circ} \mathrm{C}$. IR $(\mathrm{KBr})$ 3296, 1718, 1656, $1559 \mathrm{~cm}^{-1} ;{ }^{1} \mathrm{H}$ NMR (400 MHz, $\left.\mathrm{CDCl}_{3}\right) \delta$ 2.31 (s, 3H), 2.93 (d, $J=5.0 \mathrm{~Hz}, 3 \mathrm{H}$ ), 3.41 (dd, $J=18.2,12.1$ $110 \mathrm{~Hz}, 1 \mathrm{H}$ ), 3.52 (dd, $J=18.2,7.2 \mathrm{~Hz}, 1 \mathrm{H}$ ), 5.05 (dd, $J=12.1$, 7.2 Hz, 1H), 6.45-6.5 (br, $\left.1 \mathrm{H}) ;{ }^{13} \mathrm{C} \mathrm{NMR} \mathrm{(100} \mathrm{MHz,} \mathrm{CDCl}_{3}\right) \delta$ $26.2\left(\mathrm{CH}_{3}\right), 26.3\left(\mathrm{CH}_{3}\right), 36.1\left(\mathrm{CH}_{2}\right), 85.7(\mathrm{CH}), 153.8(\mathrm{C})$, 159.3 (C), 205.1 (C); MS (FAB) $171\left(\mathrm{M}^{+}+1,100\right)$. Anal. Calcd for $\mathrm{C}_{7} \mathrm{H}_{10} \mathrm{~N}_{2} \mathrm{O}_{3}$ : C, 49.41; H, 5.92; N, 16.46\%. Found: C, 115 49.13; H, 5.53; N, 16.42\%.

Methanolysis of nitroisoxazolone 5a. A solution of 
nitroisoxazolone 5 a $(72 \mathrm{mg}, 0.50 \mathrm{mmol})$ in methanol $(5.0 \mathrm{~mL})$ was stirred at $30{ }^{\circ} \mathrm{C}$ for 1 day. After removal of the solvent under reduced pressure, the reaction mixture was extracted with benzene $(10 \mathrm{~mL} \mathrm{x} \mathrm{3).} \mathrm{The} \mathrm{organic} \mathrm{layer} \mathrm{was} \mathrm{concentrated,}$ 5 and the residue was subjected to column chromatography to afford a mixture of $\mathbf{1 8}$ and 3d (eluted with hexane/ $\mathrm{CHCl}_{3}=$ 2/1, $23 \mathrm{mg}$, yield of 18; 18\%, yield of $\mathbf{3 d}$; 12\%) and nitroenamine 18 (eluted with hexane $/ \mathrm{CHCl}_{3}=1 / 1,30 \mathrm{mg}$, $0.23 \mathrm{mmol}$, yield 46\%). Although further purification of 3d 10 was attempted by column chromatography again, impurity could not be removed. The structural determination was performed by comparing spectral data with those of $\mathbf{3 e}$, which was prepared from commercially available ethyl nitroacetate and ethyl isocyanate.

15 1-Methoxy-1-methylamino-2-nitroethene (18). Colorless plates. Mp 110-112 ${ }^{\circ} \mathrm{C}$. IR (Nujol) 3327, 1662, $1564 \mathrm{~cm}^{-1} ;{ }^{1} \mathrm{H}$ NMR (400 MHz, $\left.\mathrm{CDCl}_{3}\right) \delta 3.00$ (d, $J=5.2 \mathrm{~Hz}, 3 \mathrm{H}$ ), 3.88 (s, $3 \mathrm{H}), 6.67$ (s, 1H), 9.6-10.0 (br, $1 \mathrm{H}) ;{ }^{13} \mathrm{C} \mathrm{NMR} \mathrm{(100} \mathrm{MHz,}$ $\left.\mathrm{CDCl}_{3}\right) \delta 27.3\left(\mathrm{CH}_{3}\right), 56.9\left(\mathrm{CH}_{3}\right), 97.9(\mathrm{CH}), 165.1(\mathrm{C}) ; \mathrm{MS}$

20 (EI) $132\left(\mathrm{M}^{+}, 100\right)$. HRMS Calcd for $\mathrm{C}_{4} \mathrm{H}_{8} \mathrm{~N}_{2} \mathrm{O}_{3}$ : 132.0535 . Found: 132.0531. Anal. Calcd for $\mathrm{C}_{4} \mathrm{H}_{8} \mathrm{~N}_{2} \mathrm{O}_{3}$ : C, 36.36; $\mathrm{H}$, 6.16; N, 21.20\%. Found: C, 36.21; H, 6.19; N, 21.53\% .

Methyl 4-Aza-2-nitro-3-oxopentanoate (3d). Yellow oil. IR (neat) 3325, 1759, 1686, 1568, $1304 \mathrm{~cm}^{-1} ;{ }^{1} \mathrm{H}$ NMR (400 MHz, $\left.{ }_{25} \mathrm{CDCl}_{3}\right) \delta 2.94$ (d, $\left.J=5.0 \mathrm{~Hz}, 3 \mathrm{H}\right), 3.92$ (s, 3H), 5.90 (s, $\left.1 \mathrm{H}\right)$, 7.2-7.5 (br, $1 \mathrm{H}) ;{ }^{13} \mathrm{C}$ NMR $\left(100 \mathrm{MHz}, \mathrm{CDCl}_{3}\right) \delta 27.4\left(\mathrm{CH}_{3}\right)$, $54.9\left(\mathrm{CH}_{3}\right), 89.1(\mathrm{CH}), 158.9(\mathrm{C}), 165.1(\mathrm{C})$.

Ethyl 4-Aza-2-nitro-3-oxohexanoate (3e). Yellow solid. Mp 45-46 ${ }^{\circ} \mathrm{C}$. IR (melt) 3308, 1755, 1682, 1570, $1304 \mathrm{~cm}^{-1} ;{ }^{1} \mathrm{H}$ 30 NMR (400 MHz, $\mathrm{CDCl}_{3}$ ) $\delta 1.12$ (t, $J=7.2 \mathrm{~Hz}, 3 \mathrm{H}$ ), 1.35 (dd, $J=7.2,7.2 \mathrm{~Hz}, 3 \mathrm{H}), 3.40(\mathrm{dq}, J=7.2,5.6 \mathrm{~Hz}, 2 \mathrm{H}), 4.30-4.35$ (m, 2H), 5.77 (s, 1H), 7.0-7.2 (br, 1H); ${ }^{13} \mathrm{C}$ NMR (100 MHz, $\left.\mathrm{CDCl}_{3}\right) \delta 13.7\left(\mathrm{CH}_{3}\right), 14.1\left(\mathrm{CH}_{3}\right), 35.4\left(\mathrm{CH}_{2}\right), 64.2\left(\mathrm{CH}_{2}\right)$, 88.9 (CH), 157.8 (C), 161.5 (C); MS (EI) 204(5), 72 (21). 35 HRMS Calcd for $\mathrm{C}_{7} \mathrm{H}_{12} \mathrm{~N}_{2} \mathrm{O}_{5}$ : 204.1806. Found: 204.1809.

\section{Computational Methods}

All calculations were performed with the Firefly Quantum Chemistry Package. $^{28}$ The DFT with the B3LYP functional ${ }^{29}$ 40 and the $6-31+G^{* *}$ basis sets were used for the geometry optimization. No imaginary frequency and one imaginary frequency were ascertained for each equilibrium geometry and transition state, respectively. IRC calculation was carried out to check that the transition state connected reactant and 45 product. The energy was evaluated at $298 \mathrm{~K}$ with the evaluated potential energy and the evaluated zero-point energy.

\section{Acknowledgements}

50 This work was supported by Kyoto-Advanced Nanotechnology Network from the Ministry of Education, Culture, Sports, Science and Technology, Japan. Authors are grateful to Prof. Kiyomi Kakiuchi, Nara Institute of Science and Technology, for his kind assistance.

55

\section{Notes and references}

${ }^{a}$ School of Environmental Science and Engineering, Kochi University of Technology, Tosayamada Kami, Kochi 782-8502, Japan. Fax: +81 887 57 2520; Tel:+81 88757 2517; E-mail: nishiwaki.nagatoshi@kochi60 tech.ac.jp

${ }^{b}$ Department of Chemistry, Osaka Kyoiku University, Asahigaoka,

Kashiwara, Osaka 582-8582, Japan.

† Electronic Supplementary Information (ESI) available: $\left[{ }^{1} \mathrm{H}\right.$ and ${ }^{13} \mathrm{C}$ NMR spectra of products $3, \mathbf{8}, \mathbf{1 1}$, and $\mathbf{1 8}$, preparative method for 65 nitroisoxazolone 5a, Cartesian coordinates of all reported structures and the energies are also available]. See DOI: 10.1039/b000000x/

1 A. Padwa, W. H. Pearson, E. C. Taylor and P. Wipf, Synthetic Application of 1,3-Dipolar Cycloaddition Chemistry toward Heterocycles and Natural Products, Wiley-Interscience (2002).

702 G. Molteni, Heterocycles, 2006, 68, 2177.

3 S. Kanemasa, Sci. Synth., 2004, 19, 17.

4 C. J. Easton, C. M. M. Hughes, G. P. Savage and G. W. Simpson, Cycloaddition Reaction of Nitrile Oxides with Alkenes in Adv. Heterocycl. Chem., 60, 261, Academic Press (1994).

755 a) D. Conti, M. Rodriquez, A. Sega and M. Taddei, Tetrahedron Lett., 2003, 44, 5327; b) G. P. Moloney, G. R. Martin, N. Mathewa, H. Hobbs, S. Dodsworth, P.-Y. Sang, C. Knight, M. Maxwell and R. C. Glen, J. Chem. Soc., Perkin Trans. 1, 1999, 2713.

6 a) R. E. Sammelson, R. B. Miller and M. J. Kurth, J. Org. Chem., $802000,65,2225$; b) M. G. Leslie-Smith, R. M. Paton and N. Webb, Tetrahedron Lett., 1994, 35, 9251.

7 B. B. Snider and Q. Che, Tetrahedron, 2002, 58, 7821.

8 a) P. A. Harris, A. Jackson and J. A. Joule, Tetrahedron Lett., 1989, 30, 3193; b) E. Kaji, K. Harada and S. Zen, Chem. Pharm. Bull., 1978, 26, 3254.

9 S. Kanemasa, S. Kaga and E. Wada, Tetrahedron Lett., 1998, 39, 8865.

10 T. Shimizu, Y. Hayashi and K. Teramura, Bull. Chem. Soc. Jpn., 1985, 58, 2519.

9011 V. P. Kislyi, A. L. Laikhter, B. I. Ugrak and V. V. Semenov, Russ. Chem. Bull., 1994, 43, 98.

12 a) L. Cecchi, F. De Sarlo and F. Machetti, Chem. Eur. J., 2008, 14, 7903; b) F. Machetti, L. Cecchi, E. Trogu and F. De Sarlo, Eur. J. Org. Chem., 2007, 4352; c) L. Cecchi, F. De Sarlo and F. Machetti, Eur. J.

$95 \quad$ Org. Chem., 2006, 4852.

13 R. Paul and S. Tchelitcheff, Bull. Soc. Chim. Fr., 1963, 140.

14 R. Huisgen and M. Christl, Chem. Ber., 1973, 106, 3291.

15 a) T. Shimizu, Y. Hayashi, H. Shibafuchi and K. Teranuma, Bull. Chem. Soc. Jpn., 1986, 59, 2827; b) T. Shimizu, Y. Hayashi, T. Ito

$100 \quad$ and K. Teramura, Synthesis, 1986, 488.

16 B. S. Huffman, R. A. Schultz and P. J. Schlom, Polymer Bull., 2001, 47, 159.

17 a) V. N. Yarovenko, S. A. Kosarev, I. V. Zavazin and M. M. Krayushkin, Russ. Chem. Bull., 2002, 51, 1504. b) V. N. Yarovenko,

105 S. A. Kosarev, I. V. Zavazin and M. M. Krayushkin, Russ. Chem. Bull., 1998, 47, 1947.

18 A. Parhi and R. W. Franck, Org. Lett., 2004, 6, 3063.

19 a) J. Romanski, C. Chpuis and J. Jurczak, Helv. Chim. Acta, 2009, 92, 1056; b) J. Romanski, J. Józwik, C. Chpuis and J. Jurczak, Helv. Chim. Acta, 2007, 90, 2116.

20 a) M. J. Kamlet, J. Org. Chem., 1959, 24, 714; b) N. Nishiwaki, T. Nogami, C. Tanaka, F. Nakashima, Y. Inoue, N. Asaka, Y. Tohda and M. Ariga, J. Org. Chem., 1999, 64, 2160; c) N. Nishiwaki, Y. Takada, Y. Inoue, Y. Tohda and M. Ariga, J. Heterocycl. Chem., 1995, 32, 473.

11521 a) M. Tamura, Y. Ise, Y. Okajima, N. Nishiwaki and M. Ariga, Synthesis, 2006, 3453; b) N. Nishiwaki, Y. Okajima, M. Tamura, N. Asaka, K. Hori, Y. Tohda and M. Ariga, Heterocycles, 2003, 60, 303.

22 N. Nishiwaki, M. Nakanishi, T. Hida, Y. Miwa, M. Tamura, K. Hori, Y. Tohda and M. Ariga, J. Org. Chem., 2001, 66, 7535.

12023 S. Higashida, H. Nakashima, Y. Tohda, K. Tani, N. Nishiwaki and M. Ariga, Heterocycles, 1992, 34, 1511.

24 N. Nishiwaki, T. Uehara, N. Asaka, Y. Tohda, M. Ariga and S. Kanemasa, Tetrahedron Lett., 1998, 39, 4851.

25 R. Nesi, S. Chimichi, F. De Sio, R. Pepino and P. Tedeschi, 125 Tetrahedron Lett., 1982, 23, 4397.

26 R. H. Prager and C. M. Williams, Heterocycles, 1999, 51, 3113. 
27 a) D. J. Woodman, W. H. Cambell and E. F. DeRose, Heterocycles, 1977, 7, 247; b) D. J. Woodman, P. M. Stonebraker and L. Weiler, J. Am. Chem. Soc., 1976, 98, 6036.
28 A. A. Granovsky, http://classic.chem.msu.su/gran/gamess/index.html. 529 a) A. D. Becke, Phys. Rev. A, 1988, 38, 3098; b) A. D. Becke, J. Chem. Phys., 1983, 98, 5648. 